\title{
Strategies for raw sheep milk storage in smallholdings: Effect of freezing or long-term refrigerated storage on microbial growth
}

\author{
A. A. L. Tribst, ${ }^{1 *}$ L. T. P. Falcade, ${ }^{1}$ and M. M. de Oliveira ${ }^{2}$ \\ ${ }^{1}$ Center for Food Studies (NEPA), University of Campinas (UNICAMP), Albert Einstein, 291, 13083-852, Campinas, Brazil \\ ${ }^{2}$ Federal Center for Technological Education Celso Suckow da Fonseca (CEFET-RJ), Voluntários da Pátria, 30, 27.600-000, Valença, Brazil
}

\section{ABSTRACT}

We assessed the effects of freezing and refrigeration over long periods on the microbiological quality of sheep milk. The raw milk was frozen in 1-L plastic bags or 5-L milk buckets and, after 1 mo, thawed at 7 or $25^{\circ} \mathrm{C}$. We evaluated these samples immediately after thawing (d 0) and after $1 \mathrm{~d}$ of storage at $7^{\circ} \mathrm{C}$. Furthermore, we stored fresh raw milk at $7^{\circ} \mathrm{C}$ for $10 \mathrm{~d}$ in the same packages and in a bulk milk cooler at $4^{\circ} \mathrm{C}$ (adding $10 \%$ of fresh raw milk daily). The total bacterial, total psychrotolerant, and proteolytic psychrotolerant counts were evaluated before and after thawing (for previously frozen milk) and daily (for refrigerated milk). The frozen-thawed milks showed no significant increase in bacterial counts immediately after thawing for all samples $(<0.7 \log \mathrm{cfu} / \mathrm{mL})$, but only the samples packaged in 1-L bags and thawed at $7^{\circ} \mathrm{C}$ remained microbiologically adequate after $1 \mathrm{~d}$ of storage. Findings of the refrigerated samples were modeled using a modified Gompertz equation, obtaining a lag phase of around 0.5 (5-L bucket), 2.6 (1-L bag), and 7.0 (bulk milk cooler) $\mathrm{d}$ for total bacterial and total psychrotolerant counts. Maximum growth rates $\left(\mu_{\max }\right)$ were 1.0 and $1.0(5-\mathrm{L}$ bucket), 1.2 and 1.3 (1-L bag) and 3.0 and 1.5 (bulk milk cooler $) \ln (\mathrm{cfu} / \mathrm{mL})$ per day for total bacteria and total psychrotolerant counts, respectively. Compared with total bacteria and total psychrotolerant bacteria, psychrotolerant proteolytic bacteria grew slowly, reaching unacceptable counts only after 9 to $10 \mathrm{~d}$ of storage. The studied methods are interesting alternatives for preserving raw sheep milk on smallholdings.

Key words: sheep milk, long-term storage, freezing/ thawing milk, microbial growth

Received September 18, 2018.

Accepted February 9, 2019.

*Corresponding author: tribst@unicamp.br

\section{INTRODUCTION}

Sheep milk is the fourth most consumed milk worldwide, with 11 million tonnes produced per year (FAOSTAT, 2016). It is characterized by having a high content of solids compared with cow milk and is mainly used to manufacture dairy products.

The microbial quality of sheep milk (counts and presence of different microorganism groups, such as mesophilic and psychrotrophic) can be affected by season, hygienic process of milking, and milking type (de Garnica et al., 2013a,b). A positive correlation was established between SCC and the presence of Staphylococcus aureus, Escherichia coli, and the total bacterial count (TBC; de Garnica et al., 2013b). In the European Community (EC), the TBC limit for milk of small ruminants is $500 \times 10^{3} \mathrm{cfu} / \mathrm{mL}$ for manufacturing products from nonpasteurized milk and $1,500 \times$ $10^{3} \mathrm{cfu} / \mathrm{mL}$ when milk is pasteurized (European Community, 1994; Directive 94/71/EC). However, both limits are considered high and indicative of poor hygienic practices or an inadequate refrigeration system (Gonzalo, 2017).

Producing sheep milk throughout the year is a challenge because of the overall low animal productivity, the seasonality of milk production, and the short lactation period (Katsiari et al., 2002). In addition, in Brazil, sheep farms are commonly small or mediumsized, which hinders large-scale production (Tribst et al., 2018).

Freezing milk is an alternative method to overcome these limitations, allowing milk to be stored for several days (so that it can be accumulated for production of dairy products) or for months (allowing off-season production), as reported by Wendorff (2001). Previous results have shown that freezing sheep milk (in volumes $<50 \mathrm{~mL}$ ) reduced pathogen species such as Staphylococcus aureus, Mannheimia haemolytica, and pathogenic Escherichia coli, even in the presence of cryopreservants (Clements et al., 2003; Smith et al., 2011), but did not alter counts of mesophilic or psychrotrophic microbiota (de Garnica et al., 2011). The reduction in certain 
Table 1. Composition $( \pm \mathrm{SD})$ of sheep milks used in the study

\begin{tabular}{|c|c|c|c|c|}
\hline Sample & Fat $(\%)$ & Protein (\%) & Lactose $(\%)$ & TS $(\%)$ \\
\hline \multicolumn{5}{|l|}{ Frozen milk } \\
\hline Farm 1 & $6.80 \pm 1.24^{\mathrm{a}}$ & $5.08 \pm 0.43^{\mathrm{a}}$ & $4.42 \pm 0.18^{\mathrm{a}}$ & $17.58 \pm 1.58^{\mathrm{a}}$ \\
\hline Farm 2 & $6.73 \pm 0.53^{\mathrm{a}}$ & $5.23 \pm 0.26^{\mathrm{a}}$ & $4.19 \pm 0.18^{\mathrm{a}}$ & $17.44 \pm 0.62^{\mathrm{a}}$ \\
\hline Farm 3 & $5.58 \pm 0.32^{\mathrm{a}}$ & $4.57 \pm 0.50^{\mathrm{a}}$ & $4.60 \pm 0.21^{\mathrm{a}}$ & $15.92 \pm 0.44^{\mathrm{a}}$ \\
\hline Farm 4 & $5.57 \pm 0.89^{\mathrm{a}}$ & $5.06 \pm 0.36^{\mathrm{a}}$ & $4.42 \pm 0.25^{\mathrm{a}}$ & $17.14 \pm 1.79^{\mathrm{a}}$ \\
\hline \multicolumn{5}{|l|}{ Refrigerated milk } \\
\hline 1-L bag/5-L milk bucket & $6.14 \pm 0.57^{\mathrm{a}}$ & $5.00 \pm 0.03^{\mathrm{a}}$ & $4.65 \pm 0.08^{\mathrm{a}}$ & $17.04 \pm 0.64^{\mathrm{a}}$ \\
\hline Bulk milk cooler & $5.27 \pm 0.27^{\mathrm{a}}$ & $4.76 \pm 0.14^{\mathrm{a}}$ & $4.35 \pm 0.10^{\mathrm{a}}$ & $15.62 \pm 0.43^{\mathrm{a}}$ \\
\hline
\end{tabular}

${ }^{a}$ Means within a column with the same letter do not differ $(P>0.05)$.

pathogens probably occurred because of the presence of ice crystals and an increase in milk mineral concentration due to freezing extracellular water, leading to an increase in the osmotic gradient. Both ice crystals and the increase in the osmotic gradient cause cell shrinkage and membrane lesions. Despite these described reductions in counts of S. aureus, M. haemolytica, and E. coli, bacteriological status after thawing remains a concern (Katsiari et al., 2002), especially when high volumes of milk are packaged and then require a long time to thaw before use.

Frozen storage can also alter the milk's physicochemical characteristics due to changes in the milk compounds (Fava et al., 2014), fat globule damage (Zhang et al., 2006), an increase in soluble calcium concentration (Koschak et al., 1981; Kljajevic et al., 2016), as well as protein destabilization and aggregation, mainly due to the high calcium content (Fontecha et al., 1993; Wendorff, 2001).

Refrigeration is another alternative for milk preservation for smallholdings in which sufficient milk volume dairy manufacturing accumulates in a few days. Various authors have studied the effect of long refrigerated storage in sheep (de Garnica et al., 2011) and goat milk (Yamazi et al., 2013; Fonseca et al., 2013; Sierra et al., 2009), noting that the maximum storage time to ensure that contaminants remain below a safe limit depends on the initial counts of bacteria (Fonseca et al., 2013), storage temperature, cooling system (Yamazi et al., 2013), and the presence of preservatives used exclusively for laboratory samples (Sierra et al., 2009; de Garnica et al., 2011).

Considering the importance of freezing or long refrigerated storage for small-scale sheep milk dairy production, we aimed to evaluate the total bacterial, psychrotolerant, and proteolytic psychrotolerant counts in sheep milk preserved using various techniques commonly used on these family farms. In addition, we determined whether these processes would change some physicochemical parameters of sheep milk that are used by producers to indirectly assess milk quality.

\section{MATERIALS AND METHODS}

\section{Sheep Milk Sample Collection}

Frozen-Thawed Assay. Fresh Lacaune sheep milk was collected in spring in Brazil (September-November 2017) from 4 farms (Sítio Bela Vista, Morungaba, Brazil; Queijaria Rima, Porto Feliz, Brazil; Queijaria Gran Sierra, Cunha, Brazil; Laticinios Alvorada, Soledade de Minas, Brazil), which supplied 3 milk samples on the same day. Each sample was obtained by mixing the milk of 10 healthy animals (10-60 d of lactation), totaling milk from 30 animals from each farm. This procedure was adopted to eliminate variability from factors such as lactation period, feeding, and genetic characteristics. Table 1 shows that this sampling procedure achieved a similar milk composition between different samples $(P$ $>0.05)$.

Refrigerated Assay. Fresh Lacaune sheep milk was collected in the spring in Brazil (December 2017) from Sítio Bela Vista (Morungaba, Brazil), which supplied 3 milk samples on the same day. Each sample was obtained by mixing the milk from 10 healthy animals (10-60 d of lactation), totaling milk from 30 animals. For the bulk milk cooler samples, milk samples were collected daily over $10 \mathrm{~d}$ (fresh milk), always using the same animal groups.

All samples were collected from the buckets of the sheep milk bucket milking machine using a 2-L beaker. Samples were then transferred for final packaging (1-L high-density polyethylene bags or 5-L polypropylene milk buckets) and the plastic bags were sealed. T-type thermocouples were inserted in the geometric center of the packages and connected to a datalogger (LogBox AA 64k, Novus, Canoas, Brazil) to monitor temperatures during the cooling processes. Afterward, samples were transported in an ice box to the Center for Food Studies laboratory (Campinas, Brazil), where samples were stored and assays were carried out. Beakers, thermocouples, and packages were sanitized using sodium hypochlorite solution $(200 \mathrm{mg} / \mathrm{L})$ for $15 \mathrm{~min}$ before use. 


\section{Frozen Sheep Milk}

Each sample (in 1-L plastic bags or 5-L plastic milk buckets) was frozen in a domestic refrigerator (model BVG24H, Brastemp, São Paulo, Brazil) to simulate the actual condition (slow freezing) of sheep milk stored on smallholdings and medium-sized farms. After freezing, samples were kept at $-18^{\circ} \mathrm{C}$ for $30 \mathrm{~d}$ and then thawed under refrigeration $\left(7^{\circ} \mathrm{C}\right)$ or at controlled room temperature $\left(25^{\circ} \mathrm{C}\right)$. After thawing completely, samples were microbiologically and physicochemically evaluated, stored for $24 \mathrm{~h}$ at $7^{\circ} \mathrm{C}$, and evaluated again. As control samples, $500 \mathrm{~mL}$ of milk was collected from each sample and used to determine the initial quality of milk immediately after milking.

\section{Refrigerated Sheep Milk}

Milk stored under refrigeration was evaluated in 3 ways: (1) 1-L plastic bags stored at $7^{\circ} \mathrm{C}$; (2) 5 -L plastic milk buckets stored at $7^{\circ} \mathrm{C}$ (to simulate the actual conditions of refrigerated milk storage in smallholdings, which is usually carried out using domestic equipment); and (3) a simulation of a bulk milk cooler at $4^{\circ} \mathrm{C}$ (milk stored in 5-L plastic milk buckets that were filled daily with $500 \mathrm{~mL}$ of fresh milk immediately after milking at $\left.30 \pm 2^{\circ} \mathrm{C}\right)$. After adding the milk, the bucket was placed in ice water bath $\left(0-1^{\circ} \mathrm{C}\right)$ and mechanically stirred to ensure heat exchange similar to that of an industrial bulk milk cooler. After the system reached the storage temperature $\left(4^{\circ} \mathrm{C}\right)$, the bucket was kept at $4^{\circ} \mathrm{C}$ until the next day. The cooling rates were measured using T-type thermocouples inserted in the geometric center of the packages and connected to a datalogger ( $\operatorname{LogBox}$ AA $64 \mathrm{k}$ ). The milk was kept under these conditions for $10 \mathrm{~d}$ and samples were collected daily for microbial and physicochemical evaluation.

\section{Microbiological and Physicochemical Assays}

Milk samples were diluted up to 8-fold in saline solution $(0.85 \% \mathrm{NaCl})$ and pour-plated onto plate count agar for TBC and in plate count agar added to sterile skim milk (10\% vol/vol, Molico, Nestlé Brazil Ltda, São Paulo, Brazil) for the psychrotolerant (TPC) and proteolytic psychrotolerant counts (PPC; Yamazi et al., 2013). The TBC were determined after incubation at $35^{\circ} \mathrm{C}$ for $48 \mathrm{~h}$ and the TPC and PPC after incubation at $7^{\circ} \mathrm{C}$ for $10 \mathrm{~d}$. For psychrotolerant counts, all colonies enumerated after incubation were recorded as TPC; then, the plates were flooded with an acetic acid solution $(8 \% \mathrm{vol} / \mathrm{vol})$ and kept at room temperature for $1 \mathrm{~h}$. Afterward, the acid solution was discarded and the remaining proteolytic halos were recorded as proteolytic psychrotolerant (Yamazi et al., 2013). The final results were expressed as $\ln \mathrm{cfu} / \mathrm{mL}$. The modified Gompertz model (equation [1]) was adjusted in the results (Galarz et al., 2016) and used to describe the bacterial growth curves in refrigerated sheep milk.

$$
\ln \frac{\mathrm{C}}{\mathrm{C}_{0}}=A \exp \left\{-\exp \left[\frac{2.781 \cdot \mu_{\max }}{A} \cdot(\lambda-t)+1\right]\right\},
$$

where $\mathrm{C}$ is the microbial population $(\mathrm{cfu} / \mathrm{mL})$ at time $t$ (d); $\mathrm{C}_{0}$ is the initial microbial population $(\mathrm{cfu} / \mathrm{mL}) ; A$ is the asymptote $\left(\ln \mathrm{C}_{\max } / \mathrm{C}_{0}\right)$, representing microbial amplitude; $\mu_{\max }$ is the maximum specific growth rate during the exponential growth phase, and $\lambda$ is the lag time $(\mathrm{h})$. The 3 parameters $\left(A, \mu_{\max }, \lambda\right)$ were calculated by nonlinear regression using CurveExpert Basic 2.0 (Hyams Development; https://www.curveexpert.net/ download/).

Additionally, $\mathrm{pH}$, acidity expressed as percent lactic acid (AOAC International, 1999), and ethanol stability (Huppertz et al., 2004) were measured after thawing the milk (frozen samples) and daily for the refrigerated samples. For ethanol stability, milk samples were mixed with an equal volume of ethanol aqueous solution $(0-60 \% \mathrm{vol} / \mathrm{vol}$ of ethanol, at 2-percentage-unit intervals) and stability was determined as the highest concentration of ethanol at which no coagulation was visually observed (Huppertz et al., 2004).

\section{Statistical Analysis}

The freezing and thawing stages in different packages and temperatures were evaluated by ANOVA and Tukey pairwise comparisons at a 95\% confidence level. The effects of the different refrigerated methods in the sheep milk physicochemical parameters and microbial growth (Gompertz parameters) were evaluated separately by ANOVA and Tukey pairwise comparisons at a 95\% confidence level. For frozen-thawed samples, the results of microbiological counts (TBC, TPC, and PPC) and physicochemical parameters were evaluated by ANOVA and comparison by the Dunnett's test, selecting the control sample as the reference and at a $95 \%$ confidence level. All results were expressed as means \pm standard deviations. Statistical analyses were carried out using XLSTAT software (version 2015.2.02, Microsoft Corp., Redmond, WA).

\section{RESULTS AND DISCUSSION}

\section{Frozen-Thawed Sheep Milk}

Knowledge of the thermal histories of processes involving conservation by heat and cold is very important 
because it characterizes the processes and identifies possible deviations and temperature oscillations that can often explain changes that the food undergoes (Sadhu, 2018). The thermal history of the sheep milk freezing process (Figure 1, A1) showed that the time required for each freezing stage was higher for milk in 5 -L buckets $(P<0.05)$ compared with that in 1-L bags. In microbiological terms, the most important parameter is stage I, which is the time required for milk to reach the phase transition temperature (approximately $-1.1^{\circ} \mathrm{C}$ ). Milk stored in $1-\mathrm{L}$ plastic bags took $4.1 \mathrm{~h}$ to reach $-1.1^{\circ} \mathrm{C}$, whereas that in 5 -L buckets needed $9.3 \mathrm{~h}$ to reach the same temperature. In contrast, for physicochemical stability, the phase transition time is the most relevant, being related to the formation of larger ice crystals when the transition time is longer. Slow formation of ice crystals may lead to increased migration of calcium outside the micelles, increasing the concentration of soluble calcium (Koschak et al., 1981; Kljajevic et al., 2016) and the large ice crystals formed result in more fat globule damage (Zhang et al., 2006).

After 1 mo of frozen storage, we thawed samples at 7 or $25^{\circ} \mathrm{C}$ (Figure 1, A2). The milk samples in 5 -L buckets maintained at $7^{\circ} \mathrm{C}$ had the slowest thawing. The 5-L samples thawed at $25^{\circ} \mathrm{C}$ and the 1 - $\mathrm{L}$ samples thawed at $7^{\circ} \mathrm{C}$ showed similar times in stages I and II, indicating that the difference in sample thickness ( $\sim 3 \mathrm{~cm}$ for 1 -L bags and $\sim 20 \mathrm{~cm}$ for 5 -L buckets) was compensated by the difference in thawing temperature. It is important to note that the surface of the containers (bags and buckets) remained at $\leq 8^{\circ} \mathrm{C}$ (data not shown) during the milk thawing process at $25^{\circ} \mathrm{C}$, which probably limited microbiological growth. In contrast, however, the temperatures of the samples thawed at $25^{\circ} \mathrm{C}$ increased rapidly after the complete phase transition (stage III, A2), requiring immediate processing to prevent a continuous increase in temperature and consequent microbial development. Thus, as can be seen in Figure 1, the thermal history of the milk subjected to freezing and thawing in different packaging and temperature conditions can vary widely and it is necessary to evaluate the effect of these different processes on milk characteristics.

Microbiological analysis showed a small variation in the TBC, TPC, and PPC after freezing in the different packages, thawing at 7 or $25^{\circ} \mathrm{C}$, and after final storage at $7^{\circ} \mathrm{C}$ (Figure 2). The TBC immediately after the different processes evaluated was $<1 \log (P>0.05)$. In contrast, thawing at $25^{\circ} \mathrm{C}$ followed by refrigerated milk storage $\left(7^{\circ} \mathrm{C}\right)$ resulted in an increase $(P<0.05)$ in the TBC in the buckets $(\sim 1.4 \log )$ and bags $(\sim 0.6 \log )$. For TPC, growth $(P<0.05)$ was observed after $1 \mathrm{~d}$ of refrigerated storage for samples thawed in buckets at $25(\sim 1.6 \log )$ and $7^{\circ} \mathrm{C}(\sim 0.9 \log )$ and in bags thawed at $25^{\circ} \mathrm{C}(\sim 0.9 \log )$. Moreover, under the same temperature of thawing, 5-L milk buckets had a tendency $(P>0.05)$ for higher counts than 1-L bags, suggesting that the use of milk buckets with volumes $>5 \mathrm{~L}$ needs to be carefully evaluated as a method for preservation of cold sheep milk. Finally, no changes in PPC were observed.

We expected the highest growth of psychrotolerant bacteria because low temperatures favor growth of this group of microorganisms compared with mesophilic microorganisms (Martins et al., 2006). Despite the low thermoresistance, psychrotrophic microorganisms (included in the psychrotolerant group) can be especially damaging to dairy products because they produce proteolytic and lipolytic enzymes, which are resistant to pasteurization and can cause defects in dairy products throughout storage, such as the development of a bitter taste and rancidity (Pinto et al., 2006). Moreover, milk from small ruminants normally has high SCC, resulting in high proteolytic activity as a consequence of high plasmin concentration induced by higher SCC (Hinz et al., 2012). The European Community has established a regulatory limit only for TBC $\left(1.5 \times 10^{6} \mathrm{cfu} / \mathrm{mL}\right.$; European Community, 1994; Directive 94/71/EC); TPC and PPC have no limit established by law, but Pinto et al. (2006) recommended a maximum count of these microorganisms of $5.0 \times 10^{6} \mathrm{cfu} / \mathrm{mL}$ (to avoid problems with psychrotolerant bacteria). Considering these limits, the studied conditions are good alternatives if the initial milk quality guarantees TBC $<100,000 \mathrm{cfu} /$ $\mathrm{mL}$ and $\mathrm{TPC}<10,000 \mathrm{cfu} / \mathrm{mL}$. Moreover, to minimize problems, we recommend that the milk be used immediately after thawing, especially if thawing is carried out at $25^{\circ} \mathrm{C}$.

Sierra et al. (2009) also observed that preservation of goat milk at $-18^{\circ} \mathrm{C}$ for $22 \mathrm{~d}$ prevents microbial growth, and de Garnica et al. (2011) showed that freezing at $-20^{\circ} \mathrm{C}$ did not change the counts of mesophilic, thermoduric, or psychrotrophic bacterial groups, whereas counts of coliforms and mammary pathogens were significantly reduced (between 0.5 and 2 log cycles). Similarly, Smith et al. (2011) showed that freezing reduces the recovery of pathogens in sheep milk, which might be explained by exposure of microorganisms to large ice crystals and an osmotic gradient (both consequences of extracellular water freezing), which could result in cell shrinkage and possibly membrane damage. The differences between the previously published papers and our results might be related to the freezing and thawing conditions and microbial groups studied, because the previous studies evaluated specific microbial reductions (of several pathogens) in samples of small volume (frozen and thawed rapidly), which do not represent typical 

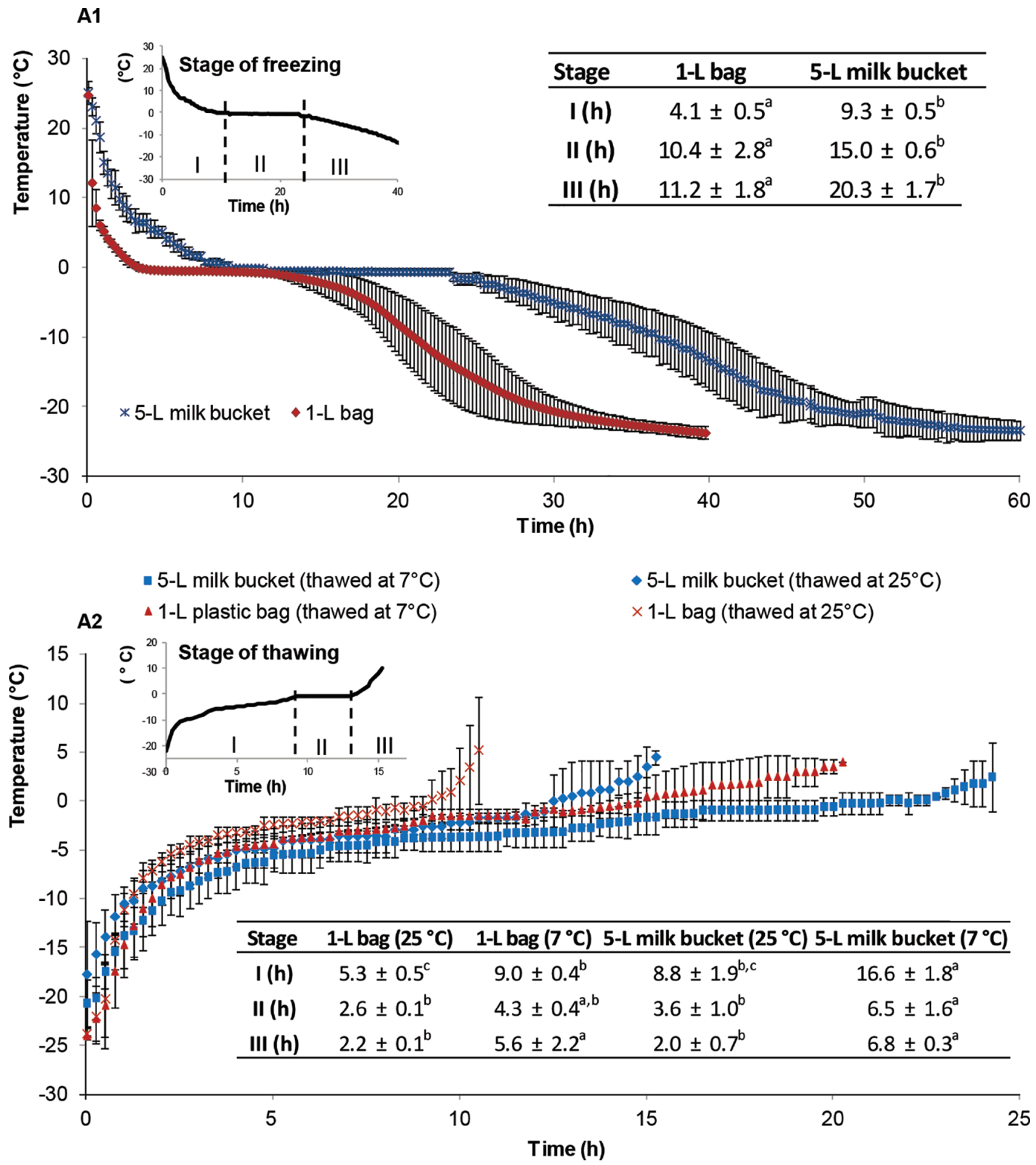

Figure 1. Thermal histories of the sheep milk freezing process in different packages $(\mathrm{A} 1)$ and thawed at 7 or $25^{\circ} \mathrm{C}(\mathrm{A} 2)$. A1: stage $\mathrm{I}=$ time (h) required for the milk to reach the phase transition temperature (from initial temperature to $-1.1^{\circ} \mathrm{C}$ ); stage $\mathrm{II}=$ time $(\mathrm{h})$ required to complete the transition phase (solidification, temperature stabilized at $-1.1^{\circ} \mathrm{C}$ ); stage $\mathrm{III}=$ time $(\mathrm{h})$ required for the milk to reach the final temperature after complete solidification (from -1.1 to $-18^{\circ} \mathrm{C}$ ). A2: stage $\mathrm{I}=$ time $(\mathrm{h})$ required for the milk to reach the phase transition temperature (from $-18^{\circ} \mathrm{C}$ to $\left.-1.1^{\circ} \mathrm{C}\right)$; stage $\mathrm{II}=$ time $(\mathrm{h})$ required to complete the transition phase (liquefaction, temperature stabilized at $-1.1^{\circ} \mathrm{C}$ ); stage $\mathrm{III}=$ time $(\mathrm{h})$ required for the milk to reach $7^{\circ} \mathrm{C}$ after the end of transition phase $\left(-1.1^{\circ} \mathrm{C}\right)$. Error bars represent the standard deviation of the sample temperatures. Inset tables: ${ }^{\mathrm{a}-\mathrm{c}}$ Values with different superscript letters in the same row differ $(P<0.05)$. 
Table 2. $\mathrm{pH}$, acidity, and stability to ethanol $( \pm \mathrm{SD})$ of sheep milk frozen in different packages, thawed at different temperatures, and stored for up to $1 \mathrm{~d}$

\begin{tabular}{|c|c|c|c|c|c|}
\hline Package & $\begin{array}{l}\text { Temperature of } \\
\text { thawing }\left({ }^{\circ} \mathrm{C}\right)\end{array}$ & $\begin{array}{l}\text { Storage at } 7^{\circ} \mathrm{C} \text { after } \\
\text { thawing }(\mathrm{d})\end{array}$ & $\mathrm{pH}$ & Acidity (\%) & $\begin{array}{l}\text { Stability to } \\
\text { ethanol (\%) }\end{array}$ \\
\hline Control & - & - & $6.56 \pm 0.04^{\mathrm{a}}$ & $0.223 \pm 0.008^{b}$ & $56.5 \pm 1.6^{\mathrm{a}}$ \\
\hline 1-L bag & 25 & 0 & $6.54 \pm 0.03^{\mathrm{a}}$ & $0.252 \pm 0.009^{\mathrm{a}}$ & $54.3 \pm 2.4^{\mathrm{a}}$ \\
\hline 1-L bag & 7 & 0 & $6.53 \pm 0.01^{\mathrm{a}}$ & $0.267 \pm 0.005^{\mathrm{a}}$ & $54.8 \pm 1.6^{\mathrm{a}}$ \\
\hline 1-L bag & 7 & 1 & $6.55 \pm 0.09^{\mathrm{a}}$ & $0.258 \pm 0.015^{\mathrm{a}}$ & $54.3 \pm 2.1^{\mathrm{a}}$ \\
\hline 5-L milk bucket & 25 & 0 & $6.57 \pm 0.05^{\mathrm{a}}$ & $0.243 \pm 0.011^{\mathrm{a}}$ & $54.5 \pm 3.7^{\mathrm{a}}$ \\
\hline 5-L milk bucket & 7 & 1 & $6.58 \pm 0.04^{\mathrm{a}}$ & $0.267 \pm 0.008^{\mathrm{a}}$ & $54.9 \pm 0.8^{\mathrm{a}}$ \\
\hline
\end{tabular}

${ }^{\mathrm{a}, \mathrm{b}}$ Dunnett's test was used to determine differences between frozen-thawed and control samples for each parameter $(P<0.05)$.

operational conditions on small to medium-sized sheep milk farms (Tribst et al., 2018).

The physicochemical evaluation of frozen-thawed sheep milk showed only a few changes in acidity after thawing and no significant alterations in the $\mathrm{pH}$ or stability to ethanol (Table 2). The small increase in acidity $(P<0.05)$ may have resulted from the low microbial growth observed (Figure 2). No further increase in acidity $(P>0.05)$ occurred after storage of the freshly thawed samples for $1 \mathrm{~d}$ at $7^{\circ} \mathrm{C}$, presumably because of the limited time and temperature for microbial de- velopment in this period (Figure 2). In addition, the psychrotrophic bacteria (which would be favored by the temperature) are not acidifying microorganisms (Martins et al., 2006). The high buffering power of sheep milk (Haenlein and Wendorff, 2006) explains the lack of changes in milk $\mathrm{pH}$. Moreover, the milk preservation conditions did not result in sufficient changes in protein to reduce its stability to ethanol, as we expected, given the relatively short storage period. Haenlein and Wendorff (2006) noted that sheep milk protein aggregation occurred only after 6 mo of freezing.

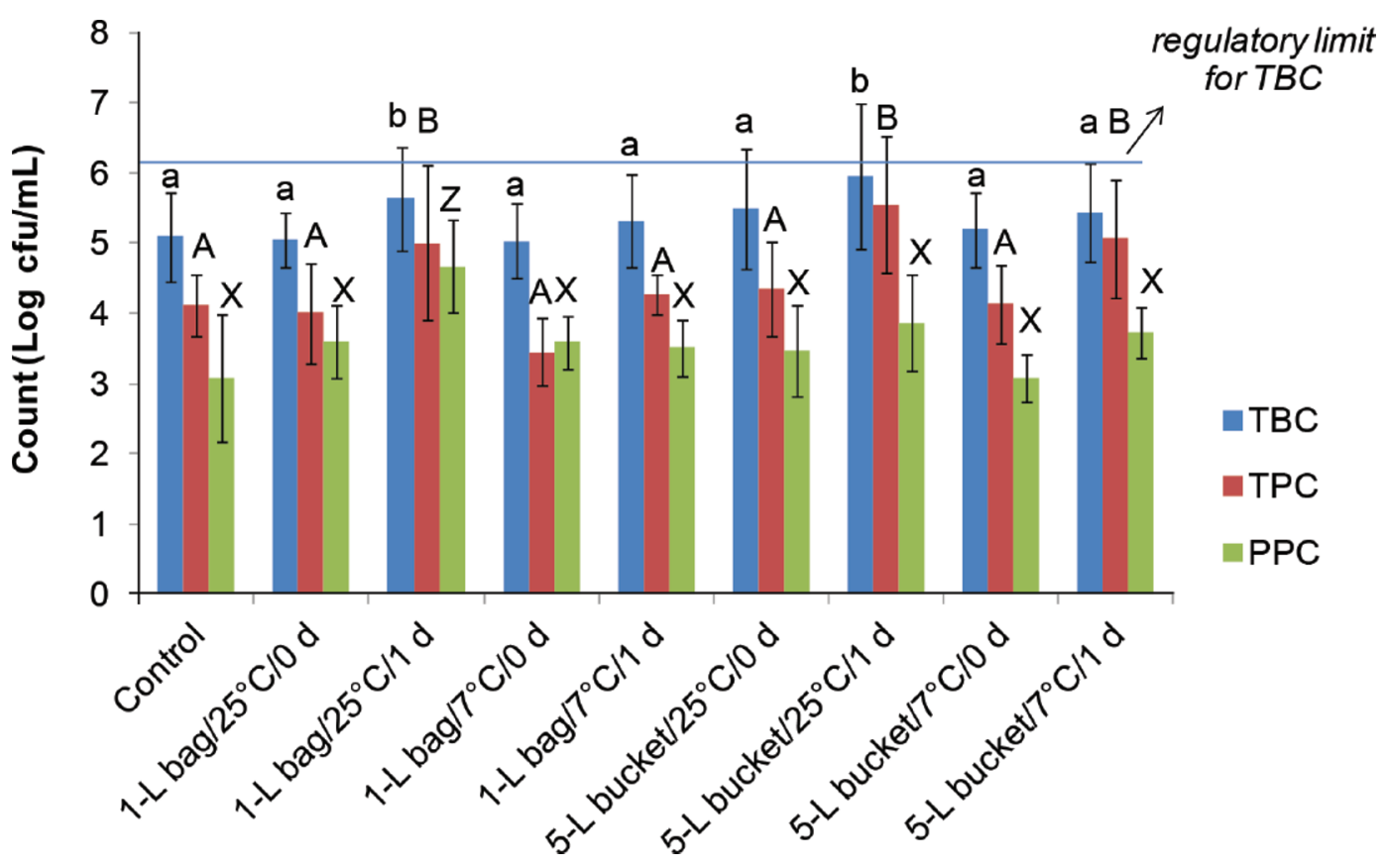

Figure 2. Microbial counts in sheep milk after freezing in different packages, thawing at 7 or $25^{\circ} \mathrm{C}$, and storing for 0 or $1 \mathrm{~d}$ at $7^{\circ} \mathrm{C}$. Dunnett's test was used to determine differences between counts after each frozen-thawed condition and counts of control sample for each microbial group. The bars represent the standard deviation of counts. Letters a and $\mathrm{b}, \mathrm{A}$ and $\mathrm{B}$, and $\mathrm{X}$ and $\mathrm{Z}$ indicate differences $(P<0.05)$ in total bacterial count (TBC), total psychrotolerant count (TPC), and proteolytic psychrotolerant count (PPC), respectively. The regulatory limit for TBC is also shown; TPC and PPC have no regulatory limits. 


\section{Refrigerated Sheep Milk}

Supplemental Figure S1 (https://doi.org/10.3168/jds .2018-15715) shows the thermal histories of the samples kept refrigerated. Packaged samples were stored at $7^{\circ} \mathrm{C}$, simulating the common operating condition of household equipment normally used for this purpose on small family farms. A comparison of results for bags $(1 \mathrm{~L})$ and buckets $(5 \mathrm{~L})$ showed that although milk in buckets took almost 3 times as long $(\sim 15 \mathrm{~h})$ to reach temperature, it remained constant throughout the 10 $\mathrm{d}$ evaluated, whereas a small temperature oscillation occurred $\left( \pm 1.5^{\circ} \mathrm{C}\right)$ in bags, which can be explained by the greater area of thermal exchange and lower thermal inertia generated by the smaller volume of milk stored in the bag.

The temperature of the bulk milk cooler sample was $4^{\circ} \mathrm{C}$, simulating the condition normally used for milk storage in this type of equipment. In this case, the hot milk $\left(30 \pm 2^{\circ} \mathrm{C}\right)$ added daily increased the average temperature of the bulk by approximately $5^{\circ} \mathrm{C}$ in the first days and by 2 to $3^{\circ} \mathrm{C}$ in the final days, because of the proportionally smaller volume of hot milk added in the final days. Small variations in the microbial counts of fresh milk were observed for TBC (4.4-4.85 log cfu/ $\mathrm{mL})$, TPC $(1.7-2.2 \log \mathrm{cfu} / \mathrm{mL})$, and PPC $(\leq 1.7 \mathrm{log}$ $\mathrm{cfu} / \mathrm{mL}$ ), which was expected considering that milk was collected daily from the same farm and following the same milking protocol. Therefore, we conclude that differences in milk microbial count on each day did not affect the microbial growth behavior in the bulk milk cooler.

The modified Gompertz equation was adjusted to the growth of total bacteria (Figure 3a), psychrotolerant bacteria (Figure 3b), and proteolytic psychrotolerant data (Figure 3c) with a good fit and $\mathrm{R}^{2}$ values $>91.3$ (for all samples except TBC in the bulk milk cooler, which had $\mathrm{R}^{2}=79.1$; Table 3 ). In this case, the model was maintained to allow an accurate comparison between the results. Moreover, as initial TBC, TPC, and PPC $\left(\mathrm{C}_{0}\right)$ were similar $(<0.5 \log$ of difference between samples), the comparison between the refrigerated storage alternatives was valid.

For TBC data (Figure 3a; Table 3), the final count was $\sim 2$ log lower for milk stored in the bulk milk cooler, affecting the growth amplitude and showing that the set temperature in the equipment $\left(4^{\circ} \mathrm{C}\right)$ limited total bacteria growth compared with samples stored in a domestic refrigerator at $7^{\circ} \mathrm{C}$. Moreover, the lag phase $(\lambda)$ and maximum growth rate $\left(\mu_{\max }\right)$ were smaller for samples stored in 5-L milk buckets, being 5 times $(\lambda)$ and $20 \%\left(\mu_{\max }\right)$ higher for samples stored in 1-L bags and $15(\lambda)$ and 3 times $\left(\mu_{\max }\right)$ higher for samples stored in the bulk milk cooler (Table 3 ).
These results directly show the effect of the long time $(\sim 15 \mathrm{~h})$ to reach temperature $\left(7^{\circ} \mathrm{C}\right)$ in 5 -L milk buckets stored in a domestic refrigerator because of the inefficient thermal exchange capacity of the equipment. Because the samples were at a high temperature for a long time, bacteria were in the exponential growth phase before the sample reached $7^{\circ} \mathrm{C}$, thus reaching the maximal allowed count quickly $(2.8 \mathrm{~d})$. Slow growth was observed for milk in 1-L bags, in which the thinness of package allowed faster heat exchange and reduced the time to reach $7^{\circ} \mathrm{C}$ to $5 \mathrm{~h}$; the bacterial count did not reach the maximum acceptable until 5.8 d. Finally, milk stored in the bulk milk cooler showed the best results, indicating that the lower storage temperature and the high heat exchange efficiency overcame the expected problems caused by adding hot milk to the system daily. Results obtained by Sierra et al. (2009) showed that goat milk preserved at 4 and $10^{\circ} \mathrm{C}$ showed significant growth after 5 and $2 \mathrm{~d}$, respectively, corroborating the results found in this work.

Similarly to TBC, final TPC (Figure 3b) was lower $(\sim 1 \log )$ for milk stored in the bulk milk cooler, reducing the growth amplitude for this sample. This effect can be attributed to a low temperature of the bulk cooler. Additionally, in terms of lag phase and maximum growth, similar growth profiles were observed for TBC and TPC for the same sample. Therefore, mesophilic and psychrotolerant growth profiles were similarly affected by storage conditions (5-L milk bucket $>1-\mathrm{L}$ plastic bag > bulk milk cooler), and the longer time to reach the maximum acceptable (TBC) or recommended (TPC, PPC) counts is related to the greater limit for psychrotolerant counts. Proteolytic psychrotolerant growth showed no differences in $\lambda$ and $\mu_{\max }$ parameters for samples stored under different conditions. Comparing the PPC and TPC growth profiles, most psychrotolerant growth in 5-L milk buckets was not proteolytic, whereas it was proteolytic in 1-L plastic bags and the bulk milk cooler. Again, this difference might be attributable to the difference in refrigeration time and to the storage temperature (almost all psychrotolerant bacteria that grew in the bulk milk cooler were proteolytic).

Comparing the time for temperature reduction in these samples (Supplemental Figure S1, https://doi .org/10.3168/jds.2018-15715) with respect to the frozen samples (Figure 1A, stage I), we observed that, for frozen samples that were initially refrigerated in an ice water bath, the efficiency of the process was much higher, taking less than $1 \mathrm{~h}$ (1-L bag) and $5 \mathrm{~h}$ (5-L milk bucket) to reach $7^{\circ} \mathrm{C}$. This difference in efficiency is attributed to the large heat removal capacity of the system (latent heat of ice melting $=334 \mathrm{~kJ} / \mathrm{kg}$ ). Therefore, we observed a direct correlation between 
-1-L bag

$\triangle 5$-L milk bucket

- Bulk milk cooler

\section{a) TBC}

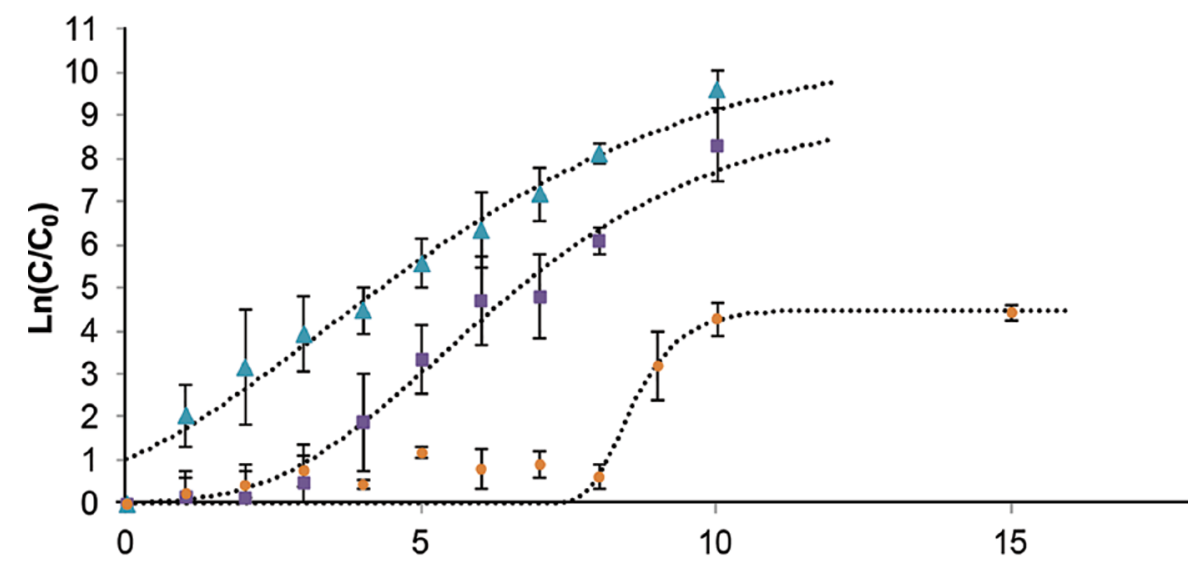

\section{b) TPC}

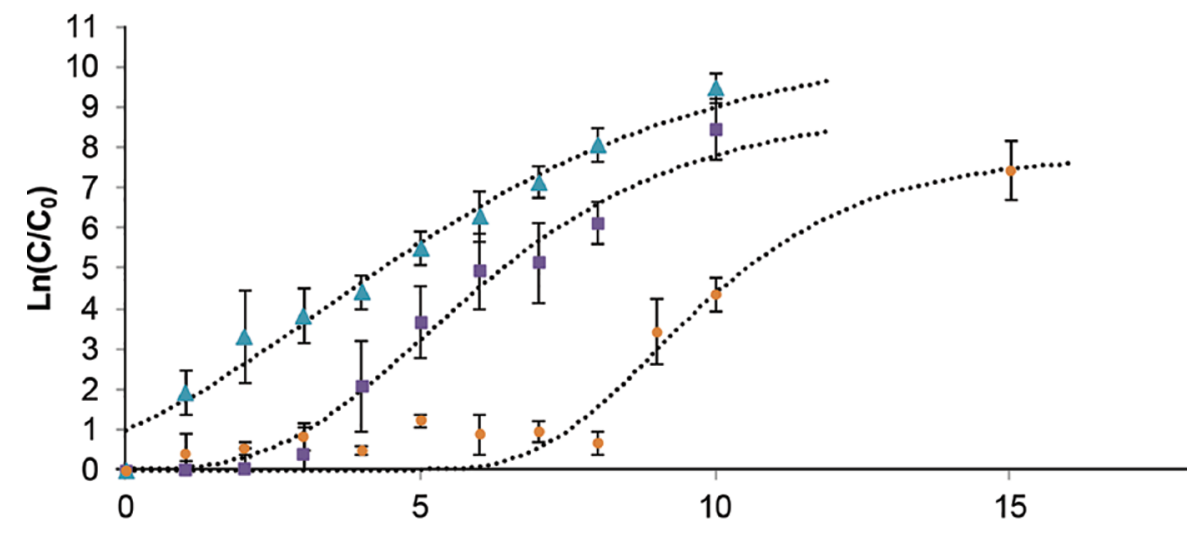

c) PPC

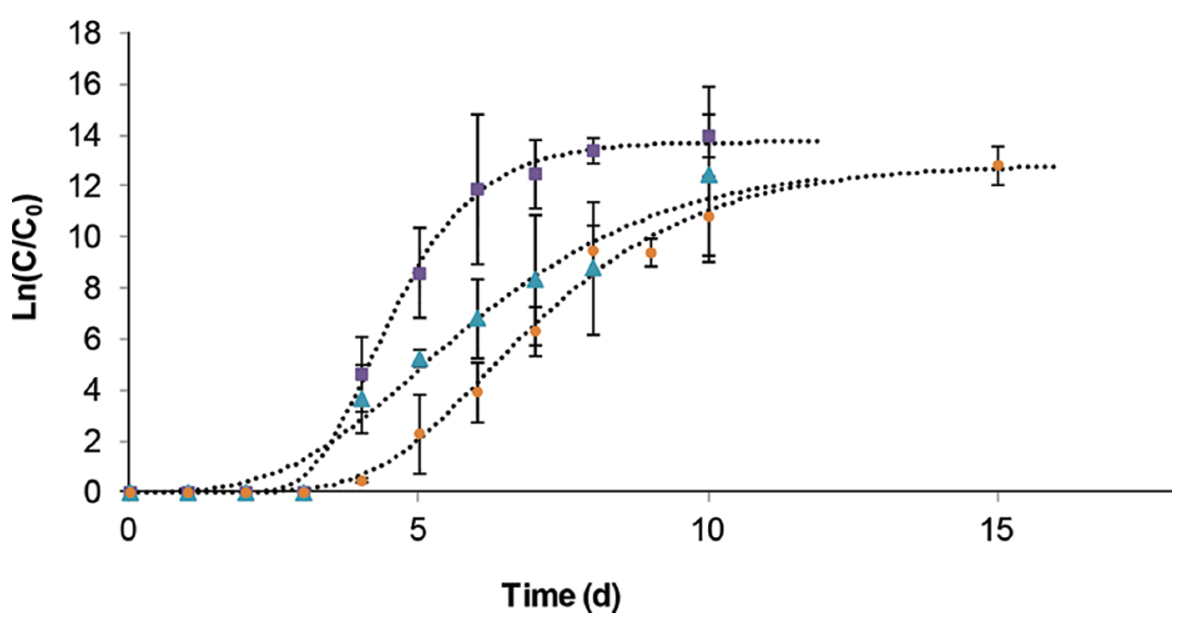

Figure 3. (a) Total bacterial count (TBC), (b) total psychrotolerant growth (TPC), and (c) proteolytic psychrotolerant growth (PPC) in sheep milk stored under different refrigeration processes. Dashed lines represent the growth behavior predicted by the Gompertz model. The bars represent the standard deviation of counts. $\operatorname{Ln}\left(\mathrm{C} / \mathrm{C}_{0}\right)=$ natural logarithm of the ratio between the microbial count at time $\mathrm{t}$ and the initial microbial count. 
Table 3. Growth parameters $( \pm \mathrm{SD})$ for total bacterial count $(\mathrm{TBC})$, total psychrotolerant count (TPC), and proteolytic psychrotolerant count (PPC; Figure 3a,b,c) in sheep milk stored under different refrigeration processes

\begin{tabular}{|c|c|c|c|}
\hline Parameter $^{1}$ & 1-L bag & 5-L milk bucket & Bulk milk cooler \\
\hline \multicolumn{4}{|l|}{ TBC } \\
\hline $\mathrm{C}_{\max }(\log \mathrm{cfu} / \mathrm{mL})$ & $8.31 \pm 0.42^{\mathrm{A}}$ & $8.87 \pm 0.14^{\mathrm{A}}$ & $6.36 \pm 0.07^{\mathrm{B}}$ \\
\hline \multicolumn{4}{|l|}{ Gompertz parameters } \\
\hline $\ln \left(\mathrm{C}_{\max } / \mathrm{C}_{0}\right)(\operatorname{ln~} \mathrm{cfu} / \mathrm{mL})$ & $9.21 \pm 2.60^{\mathrm{A}}$ & $10.87 \pm 1.79^{\mathrm{A}}$ & $4.48 \pm 0.24^{\mathrm{B}}$ \\
\hline$\mu_{\max }[\ln (\mathrm{cfu} / \mathrm{mL}) / \mathrm{d}]$ & $1.23 \pm 0.45^{\mathrm{A}}$ & $1.04 \pm 0.08^{\mathrm{A}}$ & $2.96 \pm 1.65^{\mathrm{A}}$ \\
\hline$\lambda(\mathrm{d})$ & $2.57 \pm 0.76^{\mathrm{B}}$ & $0.51 \pm 0.01^{\mathrm{C}}$ & $7.82 \pm 0.72^{\mathrm{A}}$ \\
\hline $\mathrm{R}^{2}$ model & 96.4 & 95.3 & 79.1 \\
\hline Days to reach $1.5 \times 10^{6} \mathrm{cfu} / \mathrm{mL}$ & 5.7 & 2.8 & 9.6 \\
\hline \multicolumn{4}{|l|}{$\mathrm{TPC}$} \\
\hline $\mathrm{C}_{\max }(\log \mathrm{cfu} / \mathrm{mL})$ & $8.3 \pm 0.4^{\mathrm{AB}}$ & $8.88 \pm 0.13^{\mathrm{A}}$ & $7.59 \pm 0.30^{\mathrm{B}}$ \\
\hline \multicolumn{4}{|l|}{ Gompertz parameters } \\
\hline $\ln \left(\mathrm{C}_{\max } / \mathrm{C}_{0}\right)(\operatorname{ln~} \mathrm{cfu} / \mathrm{mL})$ & $8.93 \pm 1.46^{\mathrm{AB}}$ & $10.72 \pm 1.73^{\mathrm{A}}$ & $7.81 \pm 0.75^{\mathrm{B}}$ \\
\hline$\mu_{\max }[\ln (\mathrm{cfu} / \mathrm{mL}) / \mathrm{d}]$ & $1.32 \pm 0.43^{\mathrm{AB}}$ & $1.03 \pm 0.09^{\mathrm{B}}$ & $1.46 \pm 0.11^{\mathrm{A}}$ \\
\hline$\lambda(\mathrm{d})$ & $2.55 \pm 0.49^{\mathrm{B}}$ & $0.50 \pm 1.26^{\mathrm{C}}$ & $4.21 \pm 0.22^{\mathrm{A}}$ \\
\hline $\mathrm{R}^{2}$ model & 95.9 & 95.0 & 91.3 \\
\hline Days to reach $5 \times 10^{6} \mathrm{cfu} / \mathrm{mL}$ & 5.9 & 3.8 & 10.7 \\
\hline \multicolumn{4}{|l|}{$\mathrm{PPC}$} \\
\hline $\mathrm{C}_{\max }(\log \mathrm{cfu} / \mathrm{mL})$ & $7.67 \pm 0.36^{\mathrm{A}}$ & $7.08 \pm 0.37^{\mathrm{A}}$ & $7.21 \pm 0.32^{\mathrm{A}}$ \\
\hline \multicolumn{4}{|l|}{ Gompertz parameters } \\
\hline $\ln \left(\mathrm{C}_{\max } / \mathrm{C}_{0}\right)(\operatorname{ln~} \mathrm{cfu} / \mathrm{mL})$ & $13.73 \pm 0.86^{\mathrm{A}}$ & $12.93 \pm 5.48^{\mathrm{A}}$ & $12.84 \pm 0.88^{\mathrm{A}}$ \\
\hline$\mu_{\max }[\ln (\mathrm{cfu} / \mathrm{mL}) / \mathrm{d}]$ & $4.99 \pm 1.70^{\mathrm{A}}$ & $2.02 \pm 0.64^{\mathrm{A}}$ & $2.36 \pm 0.88^{\mathrm{A}}$ \\
\hline$\lambda(d)$ & $3.15 \pm 0.13^{\mathrm{A}}$ & $2.64 \pm 0.51^{\mathrm{A}}$ & $4.21 \pm 0.86^{\mathrm{A}}$ \\
\hline $\mathrm{R}^{2}$ model & 98.4 & 94.8 & 97.7 \\
\hline Days to reach $5 \times 10^{6} \mathrm{cfu} / \mathrm{mL}$ & 6.2 & 10.0 & 10.5 \\
\hline
\end{tabular}

sample cooling time and the microbiological quality of the stored milk, with a greater refrigeration time positively affecting the growth of the microorganisms evaluated. Considering that domestic refrigeration equipment (commonly used in smallholdings for this purpose) does not allow adequate heat exchange (especially in larger packs), we suggest that, in the absence of bulk milk coolers, producers should cool milk in ice baths, preferably with stirring, and only use the refrigeration equipment to maintain the low temperature of the samples during storage. This process might ensure microbial growth closer to that observed for the bulk milk cooler, allowing milk to be stored for up to 9 to 10 $\mathrm{d}$ if the equipment is maintained at $4^{\circ} \mathrm{C}$.

From the microbiological results, we concluded that the storage limit under refrigeration should be $3 \mathrm{~d}$ (5-L milk bucket) or $5 \mathrm{~d}$ (1-L bag) for smallholdings that only have domestic refrigerators to preserve raw milk. In contrast, using a bulk milk cooler can increase the storage limit time to $9 \mathrm{~d}$, making a bulk milk cooler a potentially valuable investment to eliminate the need for milk freezing and thawing. Finally, for producers who need to accumulate milk for more than $9 \mathrm{~d}$, freezing is mandatory; in this case, milk should be frozen in packages up to $5 \mathrm{~L}$ and then used immediately after completely thawing it. It is important to emphasize that the mathematical models adjusted to our data need to be validated for other types of milk or different milk production systems. The microorganisms found in the milk microbiome vary across regions of the world (because of climate conditions and other factors); therefore, our results need to be validated before being applied to other smallholding systems.

Figure 4 shows the changes in sheep milk pH, acidity, and stability to ethanol during refrigerated storage. The $\mathrm{pH}$ of the milk remained stable for at least $5 \mathrm{~d}$ of storage, beginning to decrease $(\Delta \mathrm{pH}=-0.1)$ when the TBC exceeded $10^{7} \mathrm{cfu} / \mathrm{mL}$ (i.e. exceeded the EC limit by $1 \log$ ). This highlights the intense buffering capacity of sheep milk (Haenlein and Wendorff, 2006) and shows that $\mathrm{pH}$ is not an adequate parameter by which to monitor the quality of milk.

Acidity increased slowly during the first days of storage and increased more quickly (overnight increase of at least $0.01 \%$ of lactic acid concentration) after 5 (5-L milk bucket) and 8 (1-L bag) d. The TBC limit was achieved when acidity was between 0.252 and $0.263 \%$, with an increase between 0.028 and $0.045 \%$ of the 

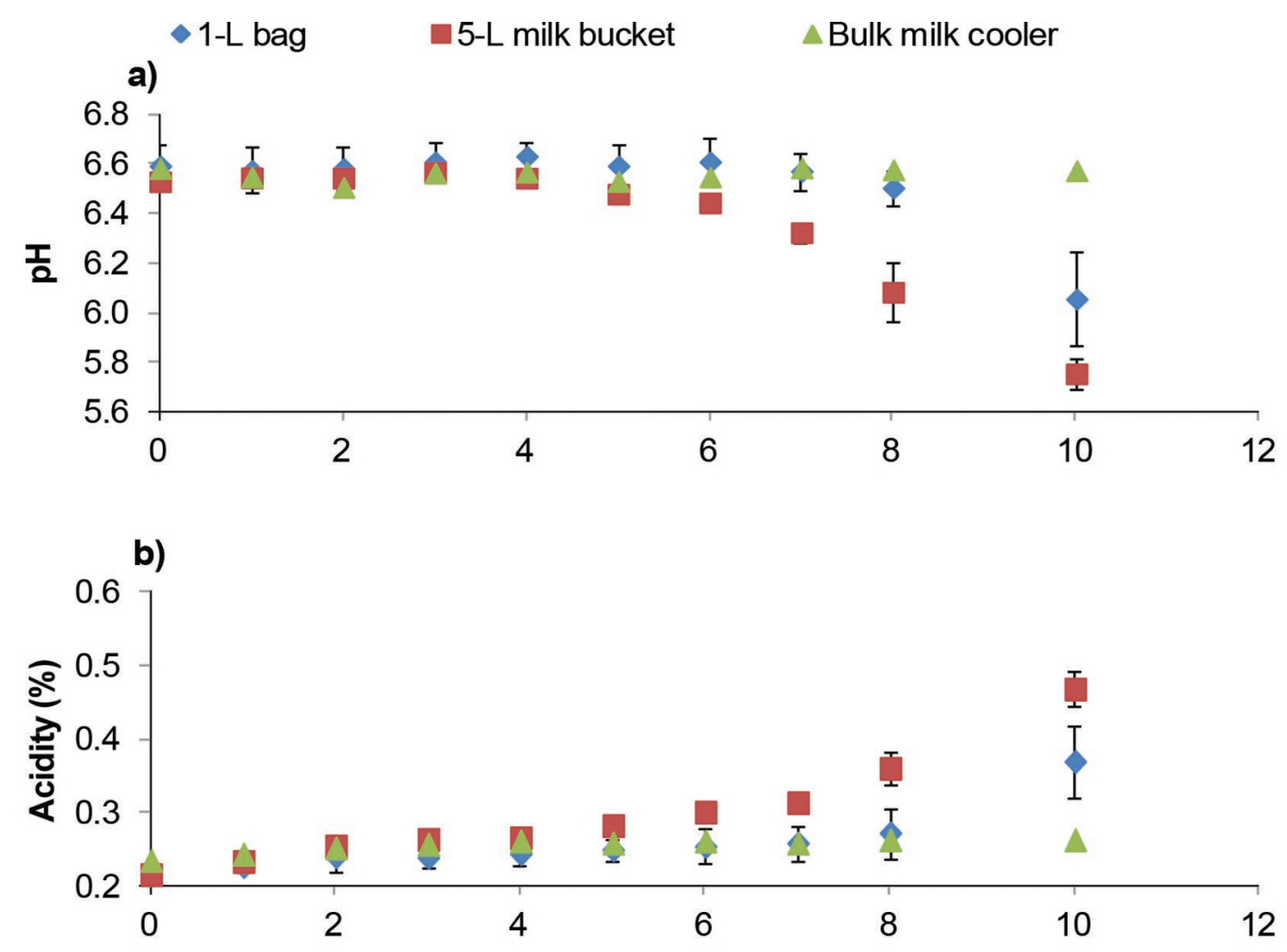

c)

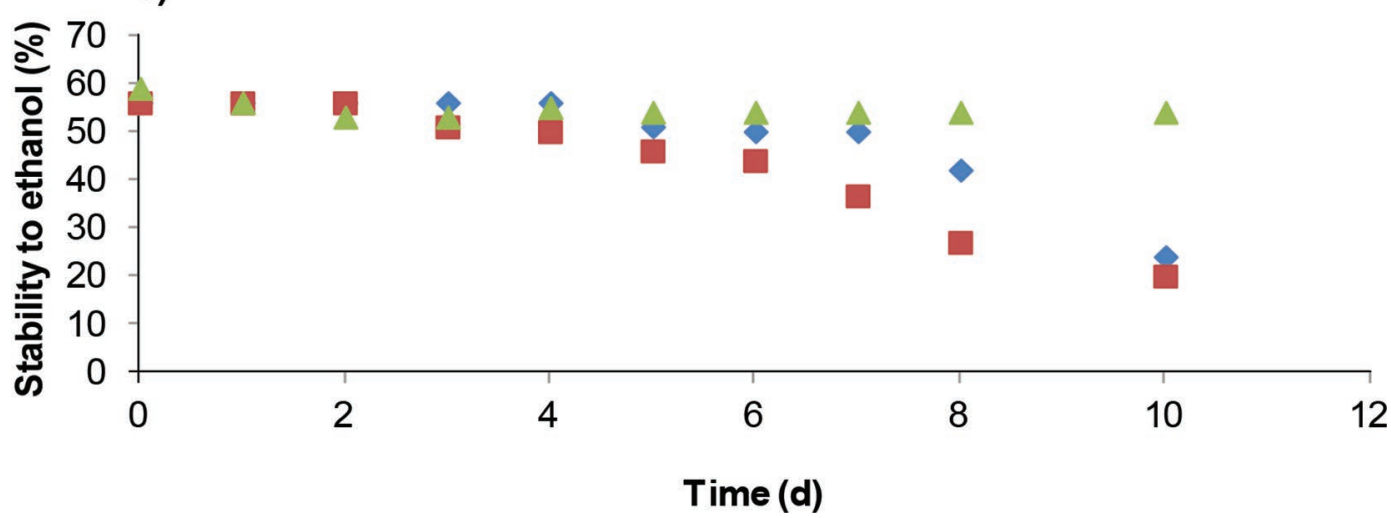

Figure 4. (a) pH, (b) acidity, and (c) stability to ethanol of sheep milk stored under different refrigeration processes. Auxiliary table shows the expected value of each physicochemical parameter when total bacterial (TBC), total psychrotolerant (TPC), and proteolytic psychrotolerant (PPC) counts reached the maximum acceptable for each sample. The bars represent the standard deviation of samples.

initial acidity of the samples. Despite these results, it is difficult to establish an acid value as a limit that guarantees the microbiological quality of the milk. This is because the natural variation of acidity in sheep milk is higher than that of cow milk, involving seasonality, lactation period, and milk composition as consequence of feed (Pavic et al., 2002; Fava et al., 2014; Todaro et al., 2014).

Results of stability to ethanol showed that samples had a visible reduction in stability (from 56 to 54 to
$50 \%$ of ethanol) around $1 \mathrm{~d}$ before significant $\mathrm{pH}$ reduction, when TBC and TPC reached $\sim 6.7 \log \mathrm{cfu} / \mathrm{mL}$. These values are above the maximum TBC established for sheep milk (European Community, 1994; Directive 94/71/EC) and the recommended TPC (Pinto et al., 2006). Therefore, stability to ethanol cannot be used as a parameter to control or assess sheep milk quality. Comparing the results obtained with those expected for nonacidic cow milk $(>72 \%)$, sheep milk had a much lower stability (56-54\%). This may be associated 
with different concentrations of milk constituents and differences in the saline balance, especially the lower sodium:potassium ratio (Guo et al., 1998) of sheep milk compared with cow milk. On the other hand, because of the high buffering capacity of sheep milk (Haenlein and Wendorff, 2006), the reduction in alcohol stability occurred only after significant production of lactic acid by mesophilic bacteria (TBC; Osman et al., 2014) plus the proteolytic action of the bacterial proteases produced by psychrotolerant microorganisms (TPC and PPC; Datta and Deeth, 2001). This explains why, for refrigerated milk, the reduction in alcohol stability occurs before the $\mathrm{pH}$ is reduced: $\mathrm{pH}$ stability is a function of the amount of accumulated acid required to overcome the buffering capacity of the milk, whereas alcohol stability will also be affected by the action of proteases. Overall evaluation of the results in Figure 4 shows that none of the 3 physicochemical parameters evaluated ( $\mathrm{pH}$, acidity, or stability to ethanol) can be used to indirectly predict the quality of sheep milk.

\section{CONCLUSIONS}

Both freezing and refrigerating sheep milk over a long time may be microbiologically suitable alternatives for milk storage until a minimum volume has accumulated for processing. However, the milk must have a good initial microbiological quality, undergo a rapid reduction in temperature (preferably using latent heat exchange rather than a static system), and be used immediately after thawing (frozen milk) or kept at the lowest possible temperature (refrigerated milk). The period over which raw milk remains adequate under refrigeration varies according to storage conditions, which can be established by modified Gompertz models adjusted to microbiological growth data. We concluded that $\mathrm{pH}$, acidity, and stability to ethanol are not useful to indirectly control the microbial quality of sheep milk.

\section{ACKNOWLEDGMENTS}

We thank Sítio Bela Vista, Queijaria Rima, Queijaria Gran Sierra, and Laticinios Alvorada for the sheep milk donations. This work was supported by São Paulo Research Foundation (FAPESP, Brazil; grant number 2017/02832-4).

\section{REFERENCES}

AOAC International. 1999. Official Methods of Analysis. 16th ed. AOAC Int., Washington, DC.

Clements, A. C., D. J. Taylor, and J. L. Fitzpatrick. 2003. Evaluation of diagnostic procedures for subclinical mastitis in meat-producing sheep. J. Dairy Res. 70:139-148. https://doi.org/10.1017/ S0022029903006022.
Datta, N., and H. C. Deeth. 2001. Age gelation of UHT milk-A review. Food Bioproducts Proc. 79:197-210. https://doi.org/10 $.1205 / 096030801753252261$.

de Garnica, M. L., B. Linage, J. A. Carriedo, J. A. Santos, and C. Gonzalo. 2013b. Staphylococcus aureus and Escherichia coli prevalence in ovine bulk tank milk. Small Rumin. Res. 115:108-112. https://doi.org/10.1016/j.smallrumres.2013.09.001.

de Garnica, M. L., B. Linage, and L. F. Fuente. 2013a. Relationship among specific bacterial counts and total bacterial and somatic cell counts and factors influencing their variation in ovine bulk tank milk. J. Dairy Sci. 96:1021-1029. https://doi.org/10.3168/ jds.2012-5915.

de Garnica, M. L., J. A. Santos, and C. Gonzalo. 2011. Influence of storage and preservation on microbiological quality of silo ovine milk. J. Dairy Sci. 94:1922-1927. https://doi.org/10.3168/jds.2010 -3787 .

European Community. 1994. Directive 94/71/EC: Directive amending Directive 92/46/EC laying down the health rules for the production and placing on the market of raw milk, heat-treated milk and milk-based products. Off. J. L368:33-37.

FAOSTAT. 2016. Statistical Database of the Food and Agriculture Organization of the United Nations. Accessed Jul., 1, 2016. http: //www.faostat.fao.org.

Fava, L. W., I. C. Külkamp-Guerreiro, and A. T. Pinto. 2014. Evaluation of physico-chemical characteristics of fresh, refrigerated and frozen Lacaune ewes' milk. Arq. Bras. Med. Vet. Zootec. 66:19241930. https://doi.org/10.1590/1678-7675.

Fonseca, C. R., K. Bordin, A. M. C. Fernandes, E. C. Rodrigues, C. H. Corassin, A. G. Cruz, and C. A. F. Oliveira. 2013. Storage of refrigerated raw goat milk affecting the quality of whole milk powder. J. Dairy Sci. 96:4716-4724. https://doi.org/10.3168/jds $.2012-6120$.

Fontecha, J., J. Bellanato, and M. Juarez. 1993. Infrared and Raman spectroscopic study of casein in cheese: Effect of freezing and frozen storage. J. Dairy Sci. 76:3303-3309. https://doi.org/10.3168/ jds.S0022-0302(93)77667-5.

Galarz, L. A., G. G. Fonseca, and C. Prentice. 2016. Predicting bacterial growth in raw, salted, and cooked chicken breast fillets during storage. Food Sci. Technol. Int. 22:461-474. https://doi.org/10 $.1177 / 1082013215618519$.

Gonzalo, C. 2017. Milk hygiene in small ruminants: A review. Spanish J. Agric. Res. 15:e05R02. https://doi.org/10.5424/sjar/2017154 $-11727$.

Guo, M. R., S. Wang, Z. Li, Z. Qu, L. Jin, and P. S. Kindstedt. 1998. Ethanol stability of goats milk. Int. Dairy J. 8:57-60. https://doi .org/10.1016/S0958-6946(98)00020-X.

Haenlein, G. F. W., and W. L. Wendorff. 2006. Sheep milk. (Chapter 3) Page 137-191 in Handbook of Milk of Non-Bovine Mammals. 1st ed. Y. W. Park and G. F. W. Haenlein, ed. Blackwell Publisher, Ames, IA.

Hinz, K., L. B. Larsen, O. Wellnitz, R. M. Bruckmaier, and A. L. Kelly. 2012. Proteolytic and proteomic changes in milk at quarter level following infusion with Escherichia coli lipopolysaccharide. J. Dairy Sci. 95:1655-1666. https://doi.org/10.3168/jds.2011-4813.

Huppertz, T., S. Grosman, P. F. Fox, and A. L. Kelly. 2004. Heat and ethanol stabilities of high-pressure-treated bovine milk. Int. Dairy J. 14:125-133. https://doi.org/10.1016/S0958-6946(03)00170-5.

Katsiari, M. C., L. P. Voutsinas, and E. Kondyli. 2002. Manufacture of yoghurt from stored frozen sheep milk. Food Chem. 77:413-420. https://doi.org/10.1016/S0308-8146(01)00367-3.

Kljajevic, N. V., S. T. Jovanovic, Z. N. Miloradovic, O. D. Macej, T. R. Vucic, and I. R. Zdravkovic. 2016. Influence of the frozen storage period on the coagulation properties of caprine milk. Int. Dairy J. 58:36-38. https://doi.org/10.1016/j.idairyj.2015.12.008.

Koschak, M. S., O. Fennema, C. H. Amundson, and J. Y. Lee. 1981 Protein stability of frozen milk as influenced by storage temperature and ultrafiltration. J. Food Sci. 46:1211-1217. https://doi .org/10.1111/j.1365-2621.1981.tb03025.x.

Martins, M. L., C. L. O. Pinto, R. B. Rocha, E. F. Araújo, and M. C. D. Vanetti. 2006. Genetic diversity of Gram-negative, proteolytic, psychrotrophic bacteria isolated from refrigerated raw milk. 
Int. J. Food Microbiol. 111:144-148. https://doi.org/10.1016/j ijfoodmicro.2006.06.020.

Osman, A., S. Mahgoub, M. El-Masry, A. Al-Gaby, and M. Sitohy. 2014. Extending the technological validity of raw buffalo milk at room temperature by esterified legume proteins. J. Food Process. Preserv. 38:223-231. https://doi.org/10.1111/j.1745-4549.2012 .00768.x.

Pavic, V., N. Antunac, B. Mioc, A. Ivankovic, and J. L. Havranek. 2002. Influence of stage of lactation on the chemical composition and physical properties of sheep milk. Czech J. Anim. Sci. $47: 80-84$.

Pinto, C. L. O., M. L. Martins, and M. C. D. Vanetti. 2006. Qualidade microbiológica de leite cru refrigerado e isolamento de bactérias psicrotróficas proteolíticas. Food Sci. Technol. (Campinas) 26:645651. https://doi.org/10.1590/S0101-20612006000300025.

Sadhu, S. P. 2018. Effect of cold chain interruptions on the shelf-life of fluid pasteurised skim milk at the consumer stage. Braz. J. Food. Technol. 21:e2017064. https://doi.org/10.1590/1981-6723.06417.

Sierra, D., A. Sánchez, A. Contreras, C. Luengo, J. C. Corrales, C. Fe, I. Guirao, C. T. Morales, and C. Gonzalo. 2009. Effect of storage and preservation on total bacterial counts determined by automated flow cytometry in bulk tank goat milk. J. Dairy Sci. 92:4841-4845. https://doi.org/10.3168/jds.2008-1988.

Smith, E. M., E. M. Monaghan, S. J. Huntley, and L. E. Green. 2011. Short communication: Preliminary investigation into the effect of freezing and a cryopreservant on the recovery of mastitis pathogens from ewe milk. J. Dairy Sci. 94:4850-4855. https://doi.org/ $10.3168 /$ jds.2010-4076.

Todaro, M., A. Bonanno, and M. L. Scatassa. 2014. The quality of Valle del Belice sheep's milk and cheese produced in the hot summer season in Sicily. Dairy Sci. Technol. 94:225-239. https://doi .org/10.1007/s13594-013-0155-0.

Tribst, A. A. L., L. R. Ribeiro, B. R. C. Leite Junior, M. M. de Oliveira, and M. Cristianini. 2018. Fermentation profile and characteristics of yoghurt manufactured from frozen sheep milk. Int. Dairy J. 78:36-45. https://doi.org/10.1016/j.idairyj.2017.10.005.

Wendorff, W. L. 2001. Freezing qualities of raw ovine milk for further processing. J. Dairy Sci. 84:E74-E78. https://doi.org/10.3168/jds .S0022-0302(01)70200-7.

Yamazi, A. K., T. S. Moreira, V. Q. Cavicchioli, R. Cristina, K. Burin, and L. A. Nero. 2013. Long cold storage influences the microbiological quality of raw goat milk. Small Rumin. Res. 113:205-210. https://doi.org/10.1016/j.smallrumres.2013.02.004.

Zhang, R. H., A. F. Mustafa, K. F. Ng-Kwai-Hang, and X. Zhao. 2006. Effects of freezing on composition and fatty acid profiles of sheep milk and cheese. Small Rumin. Res. 64:203-210. https://doi.org/ 10.1016/j.smallrumres.2005.04.025 